\title{
The Influence of Palm Kernel Cake on Haematology and Blood Chemistry of Mixed Domesticated Turkeys ( Meleagris gallopavo).
}

\author{
Ajuonuma C.O ${ }^{1}$ Egahi $\mathrm{J} \mathrm{O}^{1}$ Zekeri $\mathrm{O}^{2}$ and Ukwenya $\mathrm{S} \mathrm{O}^{2}$ \\ ${ }^{1}$ Department of Animal Breeding And Physiology Univeraity of Agriculture Makurdi \\ ${ }^{2}$ Department of Animal Production University of Agriculture Makurdi
}

\begin{abstract}
Eighty day old mixed breed and indigenous turkey poults were investigated to analyse the influence of feeding Palm kernel cake (PKC) diet on haematology and blood chemistry. The diets were 1, 2, 3, and 4 containing 0, 10, 20 and 30\% inclusion levels of PKC in the starter phase. The blood samples were obtained from the control and treatment turkeys at the end of the exposure period. While haemoglobin, packed cell volume, total protein, albumin, globulin and alanine amino transferase showed no significant differences $(P>$ $0.05)$ among the diets, aspartate amino transferase (AST), cholesterol and total red blood cells (RBC) showed significant differences $(P<0.05)$ across the diets. Provided the dietary requirements are met, PKC can be incorporated up to a level of $30 \%$ in turkey rations without adverse effects on their health.
\end{abstract}

Key words: Turkey poults, Palm kernel cake, Blood chemistry. Meleagris gallopavo

\section{Introduction}

Turkeys ( Meleagris gallopavo Linnaeus, 1758, Galliformes Meleagrididae) are birds that originated in North America that were domesticated in Europe and are now an important source of food in many parts of the world (Brant, 1998). Turkey occupies an important position next to chicken,duck, guinea fowl and quail in contributing to the most evolving sector, which is playing a significant role in augmenting the economic and nutritional status of varied population (Katie and Frazer, 1988). Turkeys were bred mainly for their beautifully coloured plumage until about 1935, after which the breeding emphasis changed to their meat qualities (Agricultural Alternatives, 2004). All over the world, turkeys are reared for their tasty and high quality meat (Prabakaran, 2003).

Haematological and blood chemistry analyses are among the methods which contribute to the detection of some changes in health status and can be useful aids for diagnosis of diseases in birds. The biochemistry of blood hence makes it possible to estimate the exchange of substances and work of the internal organs. Most reports of avian blood ranges do not state age distinctions and limited blood chemistry data are available for domestic turkeys. The current study aims at investigating the effect of palm kernel cake on blood chemistry and haematological properties in turkey. These parameters are important determinants of the health status of the birds.

\section{Materials And Methods}

Turkeys were allocated in a deep litter half walled building surrounded with strong wire mesh. The birds were assigned into four experimental diets containing 0,10, 20 and 30\% palm kernel cake. The feed was compounded of PKC, maize, groundnut cake and blood meal and other ingredients according to NRC (1994)recommendations. Each treatment was replicated twice, and the birds were given feeds and drinking water ad-libitum for a period of 10 weeks. The percentage composition of experimental diets is presented in Table 1. Blood samples were collected from the superficial ulnar vein of 80 domesticated turkeys. Aliquots of each blood sample for haematological and blood chemical analysis respectively were transfered immediately to separate tubes; one tube containing EDTA (ethylene diamine tetracetic acid) and into another tube containing no anti coagulant. Total red blood cell (RBC) counts were performed by a manual method using blood diluted on $0.01 \%$ toluidine blue stain (Zinkl, 1986). The haemoglobin concentration was measured by cyanomethemoglobin method. The packed cell volume (PCV) was determined by the microhematocrit method in capillary tubes and centrifuged at $12,000 \mathrm{~g}$ for 5 minutes. Total protein was determined using direct biuret method, while bromocresol green method of Doumas and Peters (1997) was used for determination of serum albumin. The Reitman and Frankel (1995) enzymic calorimeter test was used for determination of serum cholesterol, alanine amino transferase (AST) parameters. The data collected was subjected to analysis of variance (ANOVA) and significant means separated using Fischer's least significant difference (LSD) as outlined by Steel and Torrie (1980). Values of $\mathrm{P}<0.05$ were considered significant. 


\section{Results And Discussion}

Table 2 summarizes the influence of graded levels of PKC on haematology and blood chemistry of turkeys. The present study shows that there were no significant differences $(\mathrm{P}>0.05)$ for PCV, haemoglobin, total protein, serum albumin, serum globulin and alanine amino transferase (ALT) among the groups. Packed cell volume values of $27.59-31.75$ obtained from the present study is within the range of 22-35\% reported by Bounous et al. (2000) and comparable to the range of 30-33\% reported by Sweenson and Reece (1993) as the PCV for chicken and turkeys. The values obtained for all the diets indicate nutritional adequacy of all diets since values did not indicate under-nutrition or malnourishment (Church et. al., 1984). The haemoglobin concentration range of 9.10-10.57 g/dl recorded were within the range of 7-13g/dl reported by Bounous and Stedman (2000) but higher than 6.5- 9.0g/dl reported by Sweenson and Reece (1993). Hacbath et al. (1983) recorded a strong influence of diet on haematological traits; PCV and $\mathrm{Hb}$ being very strong indicators of nutritional status of animals. The total RBC showed significant differences $(\mathrm{P}<0.05)$ among the diets. Normal ranges of 2.5-3.5 x 10 and 2.5-3.2 x 10\% $/ \mathrm{mm}^{3}$ were respectively reported by Bounous and Stedman (2000) as well as Sweenson and Reece (1993). Hacbath et al. (1983) reported that increased RBC values were associated with high quality protein and with disease-free animals. The results obtained for PCV, $\mathrm{Hb}$ and RBC in the present study are similar to values reported for the same birds in Nigeria (Makinde and Fatumbi, 1985; Oyemale and Ajibade (1990).

Serum albumin and globulin levels obtained in this study were not significantly $(\mathrm{P}>0.05)$ different amongst the diets and these values are in close agreement with those reported by Silva et al. (2007) and Moreira et al. (2010) respectively. Aspartate amino transferase (AST) values showed significant $(\mathrm{P}<0.05)$ differences among the dietary treatments. The values in this study are similar to values recorded for 16 weeks-old female Japanese quails (Scholtz et.al., 2009) and bronze turkeys (Moreira et. Al., 2010). Aspartate amino transferase values are age dependent among different species and the care of this age dependent increase has not been defined (Hochleithner, 1994). The values of alanine amino transferase (ALT) obtained in the current study were slightly higher than values of 0-10 iu/L considered "normal" by Schmidt et al.(2007). According to Harr (2006) differences in methodologies for measuring ALT may account for differences in reference values and enzyme activity in normal birds. Serum cholesterol values obtained in this study were significantly $(\mathrm{P}<0.05)$ affected by the dietary treatments. The values were similar to those reported by Bounous et al. (2000). Some little variations in the mean values were reported by Rajman et al.(2006) to be related to the difference in sex of the animal concerned and the dietary inclusion.

\section{Conclusion}

Red blood cells, aspartate amino transferase and cholesterol levels showed significant differences $(\mathrm{P}<0.05)$ among the dietary treatments. The haematological and blood chemistry data obtained in this study can be considered preliminary reference values, which are particularly important for turkey production.

Table 1: Percentage Composition of Experimental Diets

Ingredients Diets

\begin{tabular}{lcccc} 
& $\mathrm{T}_{1}(0 \%)$ & $\mathrm{T}_{2}(10 \%)$ & $\mathrm{T}_{3}(20 \%)$ & $\mathrm{T}_{4}(30 \%)$ \\
\hline Palm Kernel Cake & 0 & 10 & 20 & 30 \\
Groundnut Cake & 38.22 & 36.55 & 34.84 & 33.13 \\
Blood Meal & 7.65 & 7.31 & 6.97 & 6.63 \\
Maize & 33.32 & 27.94 & 22.67 & 17.39 \\
Maize Offal & 16.66 & 13.97 & 11.33 & 8.70 \\
Bone meal & 3.00 & 3.00 & 3.00 & 3.00 \\
Methionine & 0.40 & 0.40 & 0.40 & 0.40 \\
Salt & 0.30 & 0.30 & 0.30 & 0.30 \\
Premix & 0.25 & 0.25 & 0.25 & 0.25 \\
Lysine & 0.25 & 0.25 & 0.25 & 0.25 \\
Total & 100.00 & 100.00 & 100.00 & 100.00 \\
\hline
\end{tabular}

Calculated Analysis

\begin{tabular}{lcccc}
\hline Me $(\mathrm{Kcal} / \mathrm{kg})$ & 2788 & 2699 & 2614 & 2531 \\
Crude protein & 27.90 & 27.90 & 27.90 & 28.00 \\
Crude Fibre & 4.70 & 5.40 & 6.10 & 6.70 \\
Calcium & 1.22 & 1.23 & 1.25 & 1.26 \\
Phosphorus & 0.64 & 0.63 & 0.65 & 0.66 \\
Methionine & 0.75 & 0.76 & 0.78 & 0.79 \\
Lysine & 1.34 & 1.34 & 1.34 & 1.34 \\
\hline
\end{tabular}


Premix:

Supplied per Kg of diet: 5,000 iu Vitamin A; 1,000,000 iu Vitamin $\mathrm{D}_{3} ; 800 \mathrm{mg}$ Vitamin E; 4,000 $\mathrm{mg}$ Vitamin K; 1,200mg Vitamin $\mathrm{B}_{2} ; 1,000 \mathrm{mg}$ Vitamin $\mathrm{B}_{3} ; 4 \mathrm{mg}$ Vitamin $\mathrm{B}_{12} ; 3,000 \mathrm{mg}$ Niacin; 4,000mg Vitamin C; 11,200mg Chlorine; 24,000mg Mn; 8,000mg Fe; 1,000mg Cu; 18,000mg Zn; 500mg Iodine; 48mg Selenium; Antioxidant (BHT)

Table 2 Influence of graded levels of Palm kernel cake (PKC) on haematology and blood chemistry of turkeys

\begin{tabular}{|c|c|c|c|c|c|c|}
\hline \multirow[t]{2}{*}{ Parameters } & \multicolumn{3}{|c|}{ Diets } & & \multirow[b]{2}{*}{ SEN } & \\
\hline & $1(0) \%$ & $2(10) \%$ & $3(20) \%$ & $4(30) \%$ & & \\
\hline Packed Cell Volume (\%) & 31.75 & 31.25 & 27.59 & 29.00 & 20.39 & Ns \\
\hline $\begin{array}{l}\text { Haemoglobin Concentration } \\
\text { (gldl) }\end{array}$ & 10.57 & 10.42 & 9.10 & 9.68 & 6.82 & Ns \\
\hline $\begin{array}{l}\text { Total Red Blood Cell Count } \\
\qquad\left(\times 10^{6} \mu / \mathrm{L}\right)\end{array}$ & $2.03^{\mathrm{c}}$ & $2.33^{\mathrm{b}}$ & $4.48^{\mathrm{a}}$ & $2.98^{\mathrm{b}}$ & 0.95 & $*$ \\
\hline Total Protein (glL) & 45.55 & 46.50 & 55.90 & 47.30 & 6.43 & Ns \\
\hline Serum Albumin (glL) & 19.05 & 16.35 & 21.10 & 20.50 & 1.94 & Ns \\
\hline Serum Globulin(glL) & 26.45 & 30.15 & 34.80 & 26.60 & 2.30 & Ns \\
\hline $\begin{array}{l}\text { Aspartate Amino Transfarase } \\
\text { (iu/L) }\end{array}$ & 117.50 & 207.50 & 155.5 & 230.0 & 35.92 & * \\
\hline $\begin{array}{l}\text { Alanine Amino Transfarase } \\
\text { (iu/L) } \\
\text { Serum Cholesterol (mgldL) }\end{array}$ & $\begin{array}{r}10.00 \\
101.00\end{array}$ & $\begin{array}{l}16.50 \\
95.00\end{array}$ & $\begin{array}{l}14.50 \\
84.50\end{array}$ & $\begin{array}{r}21.00 \\
117.50\end{array}$ & $\begin{array}{c}3.70 \\
4.14\end{array}$ & $*^{\text {Ns }}$ \\
\hline
\end{tabular}

SEM: Standard Error of Mean. Ns; Not Significant $(\mathrm{P}>0.05)$

- $\quad$ Significantly different $(\mathrm{P}<0.05)$

\section{References}

[1] Agriculture ALTERNATIVES. (2004). Small-Flock Turkey Production. The Pennsylvania State University, Pp 06

[2] Brant, A.W. (1998). A brief history of turkey. World's Poult. Sci. J. 44: 365-373

[3] Bounous, D.L. and Stedman,N.L.(2000). Normal Avian Heamatolgy: Chicken and Turkey. In: Feldman, B.F., Zinkl, J.G. and N.C. Jain Lippin cotts, Williams and Wilkisin, Phildelphia,Pp. 1147-1154.

[4] Bounous,D.I., Wyatt, R.D., Gibb,P.S.,Kilburn,J.V and Quist,C.F.(2000). Normal haematological and serum biochemical references interval for Juvenile wild turkeys. J Wild life Dis., 36: 393-396.

[5] Church, J.P., Judd, J.T./ Yomg, C.W. , Kabay, T.L. and Kim, W.W.(1983). Relationship among dietary constituents and specific serum clinical components of subjects eating self selecting diets. Amer. J. Clin Nutr, 40: 1338-1344

[6] Doumas, B.T. and Peters, T.Jr. (1997). Serum and Urine Albumin: a progress report on their measurement and clinical significance. Clin. Chim Acta 258-320

[7] Hackbath, H., Buron, K. and Schimansley, G.(1983) Strain difference in inbred rats: Influence of strain and diet on haematological traits. Lab. Anim., 17:7-12

[8] Harr, K. (2006). Diagnostics value of Biochemistry In: Harrison, G.J. and T. L. Lightfoot Clinical Avian Medicine, Vol. II Spix Publishing, Florida. Pp 223-245

[9] Katie,T. and Frazer, A. (1988). The Complete Book of Raising Livestock and Poultry. Macmillan Publishers Ltd.

[10] Makinde, M.O. and Fatumbi, O.O. (1985). Some haematological and biochemical values of turkeys in Ibadan, Bull. Anim Hlth. Prod. Afri. 33: 245-248.

[11] Moreira, M.S., Schmidt, S.D. and Paulilo, A. C. (2010). Int. Jour. of Poult Sci. 9(20): 177-179

[12] National Research Council (1994). Nutrient Requirements of Poultry. $9^{\text {th }}$ Rev. Edn. National Academy Press Washington D.C, pp: 35-39

[13] Probakaran,R.(2003). Good practices in planning and management of integerated commercial poultry production in South Asia. FAO Animal Production and Health Paper- 159,Pp: 71-86.

[14] Rajman, M., Jurani, M and Lamosova, D. (2006). The effects of feed restriction on plasma biochemistry in growing meat type chickens. Comparative biochemistry and physiology. 145: 363-371.

[15] Reitman, S. and Frankel, S. (1957). A Colometric method for determination of serum glutamic oxaloacetic and glutamic pyruvic transaminases. Amer. Journ. Of Clin. Pathology (8): 56-62.

[16] Oyewale, J.O. and Ajibade, H.A.(1990). The osmotic fragility of erythrocytes of turkeys of two age groups vet. Archiv. 60, $91-100$

[17] Scholtz, N. Halle,I., Flachowsky, G.F. and Saverwein, H.(2009). Serum chemistry Valuesin Adult Quail. Including Sex Related Differences. Poult. Sc. 88: 1186-1190.

[18] Steel, R.G.D. and Torrie, J.H. (1960) Principles and Procedures of Statistics Mc Graw-Hill Book Co. Inc. New York.

[19] Schmidt, E.M., Paulilio, A.C., Martins, R.G. and Faglian,J.J. (2009). Haematology of the Bronze Turkey (Meleagris gallopavo): variations with Age and Gender. Int. Journ. Of Poult. Sci 8(8) 752-754.

[20] Sweenson, M.J. and Reece, W.O. (1993). Duke's Physiology of Domestic Animals. $11^{\text {th }}$ Edn. Cornell University Press. New York.

[21] Silva, P.R. L., Freita, O. C and Faglairi, J.J. (2007). Brazilian Journ. Of Poult. Sci. Vol 9 (4) $229-232$.

[22] Zinkl, J.G. (1986). Avian Haematology. In: Jain, N.C.(Ed) Schalm's Veterinary Haematology, $4^{\text {th }}$ Ed. Lea and Ferbiger, Philadelphia, Pp.: 268-270. 